\title{
En svensk barnlitteraturhistoria
}

Vid tillträdet som chef för Svenska barnboksinstitutet var en av mina målsättningar att arbeta för ett flerbandsverk om den svenska barnoch ungdomslitteraturens historia. När Utbildningsdepartementet nu ytterst glädjande beviljat institutet ett riktat anslag för ändamålet kan arbetet inledas med detta oerhört viktiga projekt. Min företrädare Sonja Svensson färdigställde 1989-1990 barn- och ungdomslitterära översikter för Den svenska litteraturen (Bonniers) och ledde några år senare arbetet med att möjliggöra en större svensk satsning. Den gången kunde ingen finansiering säkras. Efter lång tid kan vi nu påbörja projekteringen på allvar och samtidigt dra nytta av det arbete som då utfördes. En gedigen grund är lagd i vår svenska barn- och ungdomslitterära forskning, från Eva von Zweigbergks, Göte Klingbergs, Lars Furulands och Mary Ørvigs arbeten till dagens nya avhandlingar. Vi får heller inte glömma Lennart Hellsings mångsidiga opinionsbildning inom området. Många forskare är i arbete och läget för skapandet av en svensk barn- och ungdomslitteraturhistoria kunde inte vara mer gynnsamt. Att se den på bokhandelsdiskarna, på universitet och högskolor, i skolor, kommunbibliotek och svenska hem vet jag är en stark önskan hos många.

Projektet kommer att drivas i Svenska barnboksinstitutets regi och undertecknad kommer att fungera som medredaktör. En högt meriterad vetenskaplig huvudredaktör, professor Boel Westin, har utsetts och en mindre grupp, bestående av några av de främsta forskarna inom vårt område, kommer att konstitueras som vetenskapligt råd. Förlagskontakter har redan tagits och kvalificerade, forskningskompetenta skribenter kommer att engageras. Till dels kommer ny forskning att krävas och för det ändamålet skall medel sökas från skilda finansiärer.

Det är utomordentligt glädjande att kunna offentliggöra att Utbildningsdepartementets forskningspolitiska enhet på detta avgörande sätt bidragit till skapandet av något vi länge saknat inom det barn- och ungdomslitterära området i Sverige.

Jan Hansson, Chefför Svenska barnboksinstitutet 